\title{
Crowdfunding for Sustainability Ventures
}

\author{
Nuno Bento', Gianfranco Gianfrate', Marco Horst Thoni ${ }^{3}$ \\ 'Instituto Universitário de Lisboa (ISCTE-IUL), DINAMIA'CET, Av.das Forças Armadas, 1649-026 Lisboa, \\ Portugal. Phone: (+351) 9164160 87, Fax: (+351) 217940042 \\ Universidade Católica Portuguesa, Department of Economics, Management and Social Sciences, \\ 3504-505 Viseu, Portugal. Nuno.Bento@iscte.pt \\ ${ }^{2}$ EDHEC Business School, 393 Promenade des Anglais 393, BP3116 \\ 06202 Nice Cedex 3, France. G_Gianfrate@hks15.harvard.edu \\ ${ }^{3}$ Graduate Student, Bocconi University, Via Roberto Sarfatti 25, 20136 Milan, Italy. Phone: (+39) 3407647867, \\ marco.thoni@studbocconi.it
}

Version of April 12, 2019

\begin{abstract}
Sustainable entrepreneurship is raising and already providing a response to environmental, social and economic issues. However, it is still at disadvantage when seeks funding from traditional providers of capital. Crowdfunding has opened a new possibility for closing such funding gap. This study investigates the role of crowdfunding as a creative source of capital for ventures with sustainable orientation. The analysis seeks to understand to what extent project characteristics influence the ability to raise funds on the world leading rewardcrowdfunding platform, and, importantly, to explain their survival post-campaign. Results show that the perceived sustainable mission positively influences the outcome of the campaign. An average survival rate over $70 \%$ after one year of operations suggests the creation of healthy sustainability ventures through crowdfunding. Furthermore, a higher percentage of female cofounders improves the chances of success during and after the crowdfunding campaign. The paper discusses implications for the success of crowdfunding campaigns and their development post-campaign in sustainable entrepreneurship.
\end{abstract}

Keywords: crowdfunding, social entrepreneurship, business venturing, sustainable finance, sustainability.

10279 words 


\section{Introduction}

Sustainability entrepreneurship is often depicted as one of the most promising ways to address societal issues like poverty, corruption, and environmental concerns (Schaltegger, 2002; Schaltegger and Wagner, 2011; Bento et al., 2018). However, sustainability entrepreneurship commonly experiences obstacles to obtain sufficient funding (Fedele and Miniaci, 2010; O'Rourke, 2010) and the lack of funding is a central challenge for social ventures to overcome (Ortas et al., 2013). The embedded sustainable purpose of for profit ventures or the nondistributive nature of non-profit projects often turns them less appealing to traditional funders (Calic and Mosakowski, 2016). One relatively new alternative to turning to friends and family for smaller amounts, and to venture capitalists, business angels or banks for larger amounts, is crowdfunding (Calic and Mosakowski, 2016). The crowdfunding industry has raised very fast to reach $\$ 16.2$ billion in 2017 worldwide, from $\$ 1.5$ billion in 2011 (Massolution, 2012; Hogue, 2017).

Crowdfunding is a creative finance solution that can help addressing sustainability issues. It is often considered as a complement to the traditional forms of entrepreneurial financing (Short et al., 2017). The recurrent definition in literature describes crowdfunding as an open call, through the Internet, for the provision of financial resources to support initiatives for specific purposes (Belleflamme et al., 2010; Mollick, 2014). Although crowdfunding originated as a platform for raising funds in the creative and social sectors in exchange for nonmonetary rewards (Hemer, 2011), the link between sustainability orientation and crowdfunding has only recently started to receive attention in the literature (Vasileiadou et al., 2016; Cordova et al, 2015; Hörisch, 2015; Bento et al., 2019).

Just as there are different kind of ventures that come with varying funding goals, crowdfunding comes in different forms as well. Jovanovic (2019) distinguish between four main models of crowdfunding: reward-; equity-; donation-; and lending-based crowdfunding. In this paper we focus on reward-based crowdfunding, for which funders can be seen as early customers. The funder receives a non-monetary compensation, in return for their contribution. This is most frequently realised using a pre-selling of the final product of the venture, sometimes at an earlier date, for a better price, or with some other special benefit. This model is currently the most prevalent approach (Mollick, 2014; Jovanovic, 2019). According to ground-based research by Gerber et al. (2012), factors contributing to the popularity of reward-based 
crowdfunding include: raising funds while maintaining full control over the venture, raising awareness via social media, receiving early validation, and establishing long term relationships to the funding community.

This paper explores the sustainability projects' ability to raise funds via crowdfunding, as well as to succeed post-campaign. In particular, the paper aims to address the following question: To what extent project characteristics influence the ability to raise funds on the world leading reward-crowdfunding platform and the subsequent survival of these ventures? We analyse the characteristics of the entrepreneurial team as predictors of success in addition to the factors which have been already identified in the existing literature (e.g. the funding goal, duration of the campaign or the presence of a video). We specifically investigate how sustainability orientation influences campaign-success, as well as the post-campaign performance of the crowdfunded ventures.

Our sample comprises 869 campaigns, launched between May 2009 and February 2017 on Kickstarter. The results suggest that reward-based crowdfunding is an adequate alternative to traditional forms of financing for sustainability entrepreneurs. The perceived importance of the social or environmental mission, measured by the indication of a donation to a charitable cause, has a positive influence on the likelihood to receive sufficient funding via reward-based crowdfunding. However, the diversion of the profits to charitable causes has a negative effect for the venture post-campaign. Thus, the ability of the project to turn into a full-fledged venture seems to depend on the capacity of the sustainable entrepreneur to balance charitable promises and commitments. Furthermore, the analysis reveals that entrepreneurial teams composed of a higher percentage of female co-founders are more successful both concerning the outcome of the crowdfunding campaign and the post-campaign development. These new results contribute to put into perspective the findings of previous studies (e.g. Hörisch, 2015), and to respond to the successive calls for more studies on sustainability issues in the crowdfunding literature (e.g., Jovanovic, 2019).

The remainder of this paper is organized as follows. The subsequent section will provide a review of the existing literature on sustainable entrepreneurship, crowdfunding, and on crowdfunding initiatives with a sustainable orientation. Then, hypotheses concerning the link between sustainable orientation and successful crowdfunding initiatives are developed on the basis of the preceding section. A description of the database and the models used follows. The 
empirical analysis with regard to the suggested patterns is conducted in Section 4. Finally, this papers closes with a discussion of the main findings.

\section{Literature Review}

\subsection{Determinants of Crowdfunding Success}

Crowdfunding is an alternative and relatively new method of funding, and thus research on the selection criteria of capital providers is still in its early stage. ${ }^{1}$ The literature on funding ventures, such as venture capital and business angel, should already point to some relevant determinants. ${ }^{2}$ Management team and market characteristics are two decisive factors of success in funding ventures (Drover et al., 2017; MacMillan et al., 1986). Team quality (Franke et al., 2008; Baum \& Silverman, 2004) and team prestigious (Drover et al., 2014) are important determinants. The potential market size (Cumming et al. 2010) as well as a favourable institutional context for business (Dai et al., 2012; Gu and Lu, 2014; Li and Zahra) and entrepreneurship (Venkatarman, 2004) also matters. Other factors frequently cited include spatial proximity of venture founders and funders (Tian, 2011), preparedness of the founder's proposal (Chen et al., 2009) and the quality of the product (Baum and Silverman, 2004) and its novelty (Jell et al., 2011). However it remains uncertain whether the crowd investors should follow similar decision criteria as professional investors.

A recent and growing literature explores the determinants of successful crowdfunding campaigns. The studies confirm some of the factors identified in the more general funding ventures literature. Among these, team characteristics like board members' number, experience, management skills, education, networks (Ahlers et al., 2015), product differentiation (Hu et al., 2015), geographical proximity (Agrawal et al., 2011; 2014; Mollick, 2014; Mendes da Silva et al., 2016) and age of the venture (Ahlers et al., 2015) were confirmed as factors that improve the chances of success of crowdfunding campaigns. On the other hand, the funding goal is often associated with a lower probability of success (e.g. Mollick, 2014; Kuppuswamy and Bayus, 2017). While this is particularly true for reward-type crowdfunding

\footnotetext{
${ }^{1}$ See good reviews of this emerging literature in Moritz and Block (2016), Drover et al. (2017) and Jovanovic (2019).

${ }^{2}$ We thank one anonymous reviewer for drawing our attention for the importance to relate to the broader literature on funding ventures.
} 
(Frydryck et al., 2014; Mollick, 2014), Lukkarinen et al. (2016) find that higher amounts improve the chances of success in equity crowdfunding. In addition, the campaign duration reduces the chances of success for equity and reward crowdfunding (Frydryck et al., 2014; Lukkarinen et al., 2016; Mollick, 2014). However, Cordova et al. (2015) find evidence that contributions tend to increase with the campaign duration for reward crowdfunding in technology projects. Other factors of success include promotional activities (Kuppuswamy \& Bayus, 2013), financial rewards (Ordanini et al., 2011) and non-financial rewards (Gerber et al., 2012).

A number of studies focus on how the project is presented on the platform. Among others, factors like visualization (Koch and Siering, 2015), video pitch (Frydryck et al., 2014), the language used in the campaign description (Mitra and Gilbert, 2014; Allison et al., 2015), the specification of the project characteristics (Etter et al., 2013) or signals of preparedness (Hui et al., 2012; Mollick et al., 2014) are analysed. For example, the presence of a video and keeping the funders updated through the crowdfunding platform are found to be positively correlated with funding success, while spelling errors reduce the likelihood of success (Mollick, 2014). Project quality signals (Bi et al., 2016) like the number of backers (Lin et al., 2014) also receives attention. The connections in social networks matters, particularly of founder's (individual and territorial/external) social capital (Giudici et al., 2013; Kang et al., 2017; Lukkarinen et al, 2016; Vismara 2016), namely in terms of Facebook friends (Mollick and Kuppuswamy, 2014). In the same way social media coverage (e.g. Tweets) and features of the platform (Qiu, 2013) are important. Cultural similarity between project founders and funders (Burtch et al., 2013) and non-profit campaign (Bellflamme et al., 2013; Chen et al., 2016) are found to have significant effects in the project's chances of success. Finally campaigns that adopts an "All-Or-Nothing" strategy (i.e. no funding if the campaign fails the funding goal) more likely reach goals in general crowdfunding (Cumming et al., 2014).

Some studies find evidence that crowdfunding reduces the barriers of female entrepreneurs to raise capital. While women seeking funds via traditional channels receive funding at a much lower rate for their projects than men, they are more likely to succeed at crowdfunding (Greenberg and Mollick 2017; Frydrych et al., 2014). Marom et al. (2016) find that women enjoy higher rates of success in funding their projects than men through the Kickstarter platform. Other scholars argue that women are systematically more successful than men may be explained by linguistic differences between men and women in terms of the language they 
use (Gorbatai and Nelson, 2015). Barasinska and Schäfer (2014) find evidence for a higher success rate of female borrowers on a German peer-to-peer lending platform.

The implementation stage of the venture after the campaign is much less analyzed. The more general literature on funding ventures finds that distance reduces the amount of increments after the campaign (Tian, 2011). The institutional context also has an important effect in the success of the project in the period post-campaign (Dai et al., 2012). More specifically in terms of crowdfunding, goal adequateness is an important driver of the project success, particularly for lower amounts collected (Mollick, 2014). Other factors are the respect of the delivery timeline and project quality (Xu et al., 2016). Finally, social network (with the Facebook friends proxy), outside endorsement and team quality all improve the probability of success of project post-campaign (Mollick and Kuppuswamy, 2014).

\subsection{Crowdfunding and Sustainable Entrepreneurship}

An already consolidated literature analyses crowdfunding as a platform for raising funds in the social (as well as creative) sector in exchange for nonmonetary rewards (Hemer, 2011). Nevertheless, the link between sustainable entrepreneurship and crowdfunding has received scant attention. This paper investigates crowdfunding efforts of ventures where a social or environmental mission plays a central role and strive to become self-sustainable by means of the market.

There is a group of scholars who offer a theoretical rationale to support this surmise. Lehner (2013) for example, states that backers of crowdfunding campaigns typically do not look at business plans or collateral, but at the ideas and core values behind a project, and thus in theory, social entrepreneurial initiatives and crowdfunding should match well (see also Belleflamme et al., 2014; Drury and Stott 2011; and Rubinton, 2011). The author assumes that "the crowd will thus select the social ideas it deems worthy and needed" (Lehner, 2013, p. 297). Hemer (2011), Ibrahim (2012) as well as Bartenberger and Leitner (2013) share the same point of view. Other research takes an opposing position. Hörisch (2015) argues that other variables, such as the quality of the projects, are likely to be more important for the indicatives funding success than social orientation (see also Mollick, 2014). Hörisch (2015) posits that projects with a social mission are comparable to collective goods. Hence from a rational choice 
perspective, backers will be less likely to invest in crowdfunding projects with a social mission because those who did not contribute to the project will profit from its output as well.

More empirical analysis shed light on the dynamics of social crowdfunding that can be helpful for the analysis of sustainable ventures. Lehner and Nicholls (2014), for example, investigated the motivations of the individual players in the field of social finance by looking at the interplay between the public, private and third sectors, using crowdfunding to finance public-private partnership schemes. Capital seeker's social network is relevant for success (Lehner, 2014; Saxton and Wang, 2014) as well as some types of products like for health (Saxton and Wang, 2014). Other factors that positively affect the probability of success of the crowdfunding campaign include altruism (Burtch et al., 2013) but also government tax-reliefs (Lehner and Nicholls, 2014).

In terms of campaign design and organisation, the extension of the campaign is found to improve the rates of success (Burtch et al., 2013). Conversely to other ventures, "All-OrNothing" yields more donations but a "Direct" approach (i.e. the project remains with the money collected independently of reaching the target or not) achieves higher success rates in the crowdfunding of sustainable projects (Wash \& Salomon, 2014). On the other hand, Parhankangas and Renko (2017) focus on the linguistic style of crowdfunding campaigns and how this relates to successful fundraising. Their dataset includes next to 411 commercial ventures and 245 social ventures. The authors suggest that social campaigns have a higher probability to be started by teams that are more international and that contain more women. Moreover, social entrepreneurs need to adopt linguistic styles that help backers to better understand the social mission and feel a connection to their campaign in order to boost the success of their campaigns. Allison et al. (2015) examine linguistic style in the context of micro lending granted from crowdfunding platforms, finding that backers respond positively to a campaign that is framed as an opportunity to help others and less positively to a campaign highlighting the venture as a business opportunity.

Calic and Mosakowski (2016) examines the effect of the social as well as the environmental sustainability orientation of new crowdfunding initiatives. They found that not only a sustainability orientation positively affects the funding success of crowdfunding projects, but also enables the entrepreneurs to raise more capital from other sources. The authors also point out that one major difference of crowdfunding compared to traditional capital sources is that the values and beliefs of those who participate in crowdfunding tend to change across 
categories, and over time. In terms of the ventures with an environmental focus, Hörisch (2015) finds no positive correlation between crowdfunding projects with environmental orientation and their likelihood of successful funding. Ahlers et al. (2015) provide insights on crowdfunding of new alternative energy technologies and Genentech initiatives. With their sample of over 22,000 crowdfunding campaigns ( $7.4 \%$ cleantech campaigns), they show that crowdfunding campaigns focused on green technologies are more often started in countries with low levels of individualism and more common when oil prices are rising. Moreover, they demonstrate that, relative to non-cleantech campaigns, these campaigns are more likely to include a video pitch, have more photos and a longer description. They conclude that cleantech entrepreneurs need these soft mechanisms to mitigate information problems concerning their generally riskier projects. However, they also state that the mere fact that a project is a cleantech does not influence the campaign's outcome in itself.

Therefore, the existing literature does not provide unambiguous theoretical predictions nor empirical evidences on the relationship between the sustainability orientation of the ventures and their ability to deliver successful crowdfunding campaigns. Addressing empirically such relationship could shed light on the financing channels available to sustainability entrepreneurial ventures which are often plagued by obstacles to obtain sufficient funding (Fedele and Miniaci, 2010; O'Rourke, 2010).

The post-campaign period receives a scant attention in the literature on crowdfunding sustainable ventures. Their determinants of success remain largely unknown for the period of implementation of the project (see Table 1). This paper also aims to fill that void in the literature and improve the understanding about the factors of success in the application of crowdfunded sustainable projects. 
Table 1: Synthesis-table of the determinants of success of crowdfunding

\begin{tabular}{|c|c|c|}
\hline & Campaign & Post-campaign \\
\hline $\begin{array}{l}\text { Venture capital } \\
\text { financing }\end{array}$ & $\begin{array}{l}\text { Management team and market characteristics (MacMillan et al,, 1986), team } \\
\text { quality (Franke et al., 2008; Baum \& Silverman, 2004) team prestigious (Drover } \\
\text { et al., 2014), market size (Cumming et al., 2010) } \\
\text { Preparedness (Chen et al., 2009) } \\
\text { Spatial proximity (Tian, 2011) } \\
\text { Institutional context (Dai et al., 2012), institutional development (Gu \& Lu, } \\
\text { 2014), World Governance Index (Li \& Zahra, 2012), entrepreneurship ecosystem } \\
\text { (Venkatarman, 2004) } \\
\text { Strong product technology (Baum \& Silverman, 2004); newness (Jell et al., } \\
\text { 2011) }\end{array}$ & $\begin{array}{l}\text { Smaller amount increments with distance (Tian, 2011) } \\
\text { Institutional context (Dai et al., 2012) }\end{array}$ \\
\hline $\begin{array}{l}\text { Crowdfunding } \\
\text { (general) }\end{array}$ & $\begin{array}{l}\text { Geographical proximity (Agrawal et al., 2011, 2014; Mollick, 2014; Mendes da } \\
\text { Silva et al., 2016) } \\
\text { Cultural similarity (Burtch et al., 2013) } \\
\text { "All-Or-Nothing”' (Cumming et al., 2014) } \\
\text { Project quality signals (Bi et al., 2016); number of backers (Lin et al, 2014); } \\
\text { preparedness of campaign design (Hui et al., 2012; Mollick et al., 2014) } \\
\text { Seeker's individual and territorial/external social capital (Giudici et al., 2013; } \\
\text { Kang et al. 2017; Lukkarinen et al, 2016; Vismara 2016); Facebook friends } \\
\text { (Mollick \& Kuppuswamy, 2014) } \\
\text { Product differentiation (Hu et al., 2015) } \\
\text { (Shorter) amount and duration (Mollick 2014); (shorter) campaign duration for } \\
\text { equity and reward crowdfunding (Frydryck et al., 2014; Lukkarinen et al., 2016; } \\
\text { Mollick, 2014); higher/shorter amount for respectively equity (Lukkarinen et al., } \\
\text { 2016) and reward (Frydryck et al., 2014; Mollick, 2014) crowdfunding } \\
\text { Women (Frydrych et al., 2014) } \\
\text { Video pitch (Frydryck et al., 2014) } \\
\text { Financial rewards (Ordanini et al., 2011); non-financial rewards (Gerber et al., } \\
\text { 2012) } \\
\text { Promotional activities (Kuppuswamy \& Bayus, 2013) } \\
\text { Social media coverage (e.g. Tweets) and features of the platform (Qiu, 2013) } \\
\text { Team characteristics, i.e.: board members' number, experience, management } \\
\text { skills, education, networks (Ahlers et al., 2015) } \\
\text { Age of the venture (Ahlers et al., 2015) } \\
\text { Non-profit campaign (Belleflamme et al., 2013 ; Chen et al., 2016) }\end{array}$ & $\begin{array}{l}\text { Social network (Facebook friends), outside endorsement and } \\
\text { team quality (Mollick \& kuppuswamy, 2014) } \\
\text { Goal adequateness (shorter amounts) (Mollick, 2014) } \\
\text { Delivery timeline and project quality (Xu et al., 2016) }\end{array}$ \\
\hline $\begin{array}{l}\text { Crowdfunding in } \\
\text { sustainable } \\
\text { ventures }\end{array}$ & $\begin{array}{l}\text { Social and non-profit campaign (Belleflamme et al., 2010, 2013; Allison et al., } \\
\text { 2015; Parhankangas \& Renko, 2017); project quality (Hörisch, 2015) } \\
\text { Seeker's social network (Saxton \& Wang, 2014; Lehner, 2014) } \\
\text { Health (Saxton \& Wang, 2014) } \\
\text { "All-Or-Nothing” for more donations but “Direct” for higher success rate (Wash } \\
\text { \& Salomon, 2014) } \\
\text { Altruism (Burtch et al., 2013) } \\
\text { (Longer) campaign duration (Burtch et al., 2013) } \\
\text { Non-environnemental orientation (Hörisch, 2015); environnemental orientation } \\
\text { better than no-social orientation (Calic \& Mosakowski, 2016) } \\
\text { Government tax-reliefs (Lehner and Nicholls, 2014) } \\
\text { Countries with low individualism (Ahlers et al., 2015) } \\
\text { Soft mechanisms such as video pitch, photos and a longer description (Ahlers et } \\
\text { al., 2015) }\end{array}$ & \\
\hline
\end{tabular}




\subsection{Research hypotheses}

The ability of crowdfunding ventures to raise funds greatly depends on how potential backers perceive the quality of the project, as well as on the preparedness and passion of the entrepreneurial team (Cardon et al., 2009; Chen et al., 2009). The premise is that these signals reveal the underlying quality of the campaign, ensuring that higher-quality projects are more likely to receive funding. Mollick (2014) shows, using the degree of preparedness of the campaign as a proxy for quality, that the nature and the quality of the product or project represent major drivers of success in a crowdfunding context. In line with these results, it can be expected that his findings also hold for crowdfunding initiatives with a sustainable background. This leads to the formulation of the following hypothesis.

Hypothesis 1: Sustainable crowdfunding campaigns that show signals of quality/ commitment are more likely to reach their funding target.

Secondly, small investors engaged in crowdfunding are more likely to be individuals who invest because they are sympathetic to an idea or a project and want to support it (Schwienbacher \& Larralde, 2010). Especially for investors who consider backing a crowdfunding campaign with a sustainable element, it can be assumed that the perception of this sustainable mission affects their investment decision in analogy with the argument of Lehner (2013) for crowdfunding in social areas. Therefore, campaigns in which part of the expected profits is given to charitable causes might trigger backers' willingness to engage in funding the sustainable venture. This yields the second hypothesis.

Hypothesis 2: Sustainable crowdfunding campaigns that commit to donate a portion of the profits to charitable causes are more likely to reach their funding target.

In addition to that, following previous literature, entrepreneurial teams including at least one female co-founder, are more likely to be successful in raising funds via a crowdfunding platform (Greenberg and Mollick, 2017; see also Barasinska and Schäfer, 2014; Gorbatai and Nelson, 2015; Marom et al., 2016). One can assume that these findings are even reinforced in the context of crowdfunding of sustainable ventures given the predisposition of the backers for looking at core values behind the project (Belleflamme et al., 2014). Therefore, the third hypothesis is defined as follows: 
Hypothesis 3: Entrepreneurial teams consisting of a higher percentage of female co-founders are more likely to reach their funding target than other projects via a reward-based crowdfunding platform.

The last three hypothesis test the long-term development of successful projects, post-campaign. In the context of sustainable entrepreneurship, the acceptance of the venture idea in the public discourse is one important factor affecting the success of the call (Moshe and Lerner, 2006). Drawing on self-determination theory, intrinsic motivation might be an important factor - next to pure utility of the product - concerning the purchasing decision of potential customers of a sustainable venture. Mutatis mutandis, one can expect that the perceived importance of the sustainable mission alters the purchasing decision of potential customers and thus the longterm success of the firm.

Hypothesis 4: Sustainable ventures that showed signals of quality/ commitment during the crowdfunding campaign are more likely to succeed post-campaign.

This study looks at the effect of gender in post-campaign. Greenberg and Mollick (2017) suggests that women support crowdfunding projects initiated by women because they want to support a group underrepresented in a certain field. Based on the assumption that the same rationale alters the purchasing decision of potential customers also post-campaign, the following hypothesis is formulated.

Hypothesis 5: Sustainable ventures with a higher percentage of female co-founders are more likely to succeed post-campaign.

Finally, the commitment to allocate a portion of the future expected profits to charitable causes can have opposite effects on the success of sustainability ventures post crowdfunding campaigns. On the one hand, the commitment to support charitable causes with monetary donations can foster legitimacy (Calic and Mosakowski (2016) and the creation of the social capital (Saxton and Wang, 2014; Lehner, 2014) surrounding the venture. On the other hand, especially for start-ups, the diversion of financial resources to uses not core to the implementation of the initial commercial operations could pose existential treats. This latter consideration leads to the formulation of the following: 
Hypothesis 6: Sustainable ventures that commit to donate a portion of the profits to charitable causes are less likely to succeed post-campaign.

\section{Data and Methodology}

\subsection{Data}

The empirical analysis focuses on a unique dataset of 869 projects launched, from 2014 to 2017, by sustainable entrepreneurs drawn from the crowdfunding platform Kickstarter. The choice of Kickstarter, the largest crowdfunding platform in the US and globally, is in line with previous literature (e.g. Mollick, 2014). In order to extract the relevant data from Kickstarter, we filtered the campaigns by the following keywords: "social impact", "socially responsible", "social entrepreneurs", "socially conscious", “ethical”, “eco-friendly", "ecological", "biodegradable" and "recyclable". The choice of the words sought to conceal the obvious candidates in the study of sustainable ventures with the extant literature. The filtering was applied to all the 370,000 projects (including the unsuccessful campaigns) on Kickstarter at the moment of the extraction. Subsequently the obtained data was screened to eliminate campaigns whose intention is not to drive social change, but for which sustainability is a minor incidental characteristic. One time projects were also eliminated, since one object of this paper is the appraisal of the long-term development of successful crowdfunding initiatives.

Data comes from Kickstarters for the number of backers, the categorisation of the social cause, and the variables describing the basic features of the project. Other sources provide data for several variables that previous literature identified as relevant for the success of crowdfunding campaigns, discussed in Section 2. Commitment to donate to a charitable cause is a proxy of the potential backer's perception of the social mission of the project. Table 2 presents the variables. 
Table 2: Data on the crowdfunded projects

Data about crowdfunding campaigns is from Kickstarter

\begin{tabular}{|c|c|}
\hline Name & Description \\
\hline Goal & $\begin{array}{l}\text { The amount of \$US that the campaign seeks to raise. Since the founders will only } \\
\text { receive the funds if the goal is reached, the choice of this number is crucial. }\end{array}$ \\
\hline Pledge & The amount of \$US raised during the campaign. \\
\hline Success & $\begin{array}{l}\text { A dummy variable that indicated whether the campaign was successful. Its value } \\
\text { is one if the pledge was superior to the goal at the end of the campaign, and zero } \\
\text { otherwise. }\end{array}$ \\
\hline PledgeByGoal & $\begin{array}{l}\text { The percentage of the goal that is reached. From } 100 \% \text { onwards, the campaign } \\
\text { was successful and the founders receive the total amount pledged. If the variable } \\
\text { is below } 100 \% \text {, the founders could not draw any funds. }\end{array}$ \\
\hline Backers & The numbers of individuals that contributed to the project. \\
\hline Updates & The number of updates made by the founding team of the project. \\
\hline Comments & $\begin{array}{l}\text { The numbers of comments made by Kickstarter users (backers or potential } \\
\text { backers). This enables users to ask questions or show involvement. }\end{array}$ \\
\hline Rewards & $\begin{array}{l}\text { The number of different rewards offered in return for the contribution of potential } \\
\text { backers. }\end{array}$ \\
\hline US & $\begin{array}{l}\text { A dummy variable that indicates whether the campaign was launched in or outside } \\
\text { of the US. The value is one if launched within the US, and zero otherwise. }\end{array}$ \\
\hline Video & $\begin{array}{l}\text { Dummy variable indicating whether the campaign includes a video. The value is } \\
\text { one in case a video is included, and zero otherwise. }\end{array}$ \\
\hline Funding period & $\begin{array}{l}\text { The length of the campaign in days. Backers can only pledge during this } \\
\text { timeframe. }\end{array}$ \\
\hline Charity & $\begin{array}{l}\text { A dummy variable indicating whether the campaign is promoting that the venture } \\
\text { will use at least a part of their profit for a charitable cause. This could include } \\
\text { giving a certain percentage to charity, being a non-profit organisation or actions } \\
\text { like planting a tree for every item sold. The value is one if at least a part of the } \\
\text { profit is used for a charitable cause, and zero otherwise. The charity status of the } \\
\text { receivers has been cross-checked on Charity Navigator (2017). }\end{array}$ \\
\hline Gender & The percentage of female co-founders. \\
\hline
\end{tabular}


We also collected data on the ventures' journeys following a successful campaign. The variable Ongoing indicates whether the venture is still operational at the time of data collection. This variable takes a value of one if the venture is still active, and zero otherwise. To ensure consistency, the dataset only includes ventures with a Kickstarter campaign that was successful and ended before July 2016. Hence, it comprises all successful initiatives operated for at least one year after the end of the crowdfunding campaign. In order to determine if a venture is stil ongoing, we investigate whether the website, online shop, and Facebook page were active in January 2018.

Table 2 reports descriptive statistics on the variables describing the crowdfunding initiatives. The variable Success shows an average of 0.37 . That means only about $37 \%$ of the campaigns could reach their funding goal, while $63 \%$ were unsuccessful (cancelled and suspended campaigns are also seen as unsuccessful). This number is in line with the average success rate on Kickstarter. The average success rate of all campaigns launched via Kickstarter since its inception in 2009 is $35.83 \%$ (Kickstarter, 2017). Looking at the maximum of the variable Pledge, one can see that some projects were significantly overfunded. This also leads to a relatively high value of the variable Pledge/Goal. About $75 \%$ of the projects under consideration are in the category Environmental during the data collection process. 
Table 3: Descriptive Statistics Crowdfunded Projects

See Table 2 for the definition of the variables. Data about crowdfunding campaigns is from Kickstarter.

\begin{tabular}{llllll}
\hline Variable & Count & Mean & Median & Min & Max \\
\hline Goal & & & & & \\
Success & 869 & $21,181.68$ & $10,000.00$ & 50 & $1,100,000.00$ \\
Pledge & 869 & 0.37 & 0.00 & 0 & 1.00 \\
Backers & 869 & $9,090.47$ & $1,641.00$ & 0 & $295,978.00$ \\
PledgeByGoal & 869 & 122.09 & 25.00 & 0 & $9,293.00$ \\
Updates & 869 & 0.85 & 0.21 & 0 & 27.66 \\
Comments & 869 & 5.22 & 2.00 & 0 & 55.00 \\
Video & 869 & 20.26 & 1.00 & 0 & $1,119.00$ \\
Rewards & 869 & 0.81 & 1.00 & 0 & 1.00 \\
Fundingperiod & 869 & 9.23 & 8.00 & 1 & 43.00 \\
US & 869 & 34.09 & 30.00 & 5 & 90.00 \\
Charity & 869 & 0.64 & 1.00 & 0 & 1.00 \\
\hline
\end{tabular}

Finally, the variable Ongoing measures the long-term success of the sustainable ventures postcampaign and shows a mean of 0.7 . Hence, over $70 \%$ of the ventures under consideration were still operating at the time of data collection.

\subsection{Methodology}

In order to test the first hypothesis, regressions are estimated based on the following logit regression model:

(A) Succes $=\frac{1}{1+e^{-\left(\beta_{0}+\beta_{1} \log \text { Goal }+\beta_{2} \text { US }+\beta_{3} \text { Updates }+\beta_{4} \text { Video }+\beta_{5} \text { Rewards }\right)}}+u_{i}$

Where the dependent variable is the binary variable Success, $\beta_{0}$ is the constant term, and $u$ is a logistically distributed error term. All regressions based on this model analyse the natural logarithm of the Goal and the variable US as control variables. In this context, the funding goal 
is generally controlled for by previous literature (e.g. Mollick, 2014; Cordova et al., 2015; Kuppuswamy and Bayus, 2017). Given hitherto conducted studies one can expect a negative influence on the likelihood of success. Next to the goal, this study controls for ventures being started in the U.S. Crowdfunding might mitigate most distance-sensitive economic friction and scholars find only limited evidence that geography matters in the context of crowdfunding (Agrawal, Catalini and Goldfarb, 2011; Kuppuswamy and Bayus, 2017). However, geography might be more relevant in the context of this study. First, the data includes a relatively high share of U.S.-based initiatives (64\%) as well as a high share of initiatives with environmental orientation (75\%). The perception of environmental projects in the U.S. might differ compared to different economic, cultural and political settings. Furthermore, following Mollick (2014), the analysis is extended by degree of preparedness of the campaign as a signal of quality. Signals of quality matter to investors evaluating entrepreneurial projects (Cardon, Sudek and Mitteness, 2009) and a good pitch reflects the passion and preparedness of the entrepreneurial team, signaling quality in that way (Chen, Yao and Kotha, 2009). Thus, the variables Updates, Video and Rewards, are included in this regression. All these measures may signal that the entrepreneurial team is engaged in the process and has the qualities needed to succeed.

For the appraisal of the second and third hypotheses, Equation $A$ is extended by adding separately the variable Gender and Charity, and then considering them jointly. Respectively, the three logit regression models are:

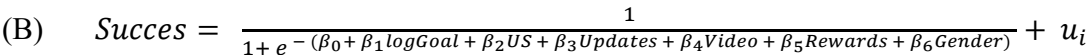

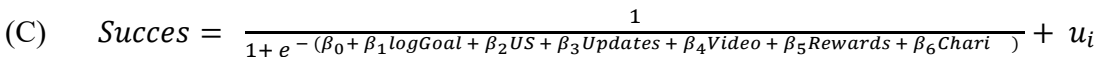

(D) Succes $=\frac{1}{1+e^{-\left(\beta_{0}+\beta_{1} \log \text { Goal }+\beta_{2} \text { US }+\beta_{3} \text { Updates }+\beta_{4} \text { Video }+\beta_{5} \text { Rewards }+\beta_{6} \text { Gender }+\beta_{7} \text { Chari }\right)}}+$ $u_{i}$

Similarly, the success of the sustainability ventures post-campaign is measured using the dichotomous variable Ongoing. Regressions are estimated based on the following logit regression model: 


\section{(E) $\quad$ Ongoing $=\frac{1}{1+e^{-\left(\beta_{0}+\beta_{i} x_{i}\right)}}+u_{i}$}

Where the dependent variable is the binary variable Ongoing, $\beta_{0}$ is the constant term, $u$ is a logistically distributed error term, and $x_{i}(i=1,2, . ., 6)$ are respectively the variables Pledge, Backers, PledgeByGoal, US, Updates, Rewards. In the final step, Equation F is extended by the variables Charity and Gender. This enables the investigation of the influence these two measures have on the post-campaign development of the project, in the following logit regression model:

$$
\text { (F) Ongoing }=\frac{1}{1+e^{-\left(\beta_{0}+\beta_{i} x_{i}\right)}}+u_{i}
$$

Where the depended variable is the binary variable Ongoing, $\beta_{0}$ is the constant term, $u$ is a logistically distributed error term, and $x_{i}(i=1,2, . ., 8)$ are respectively the variables included in Equation E along with Charity and Gender.

\section{Results}

\subsection{Sustainable Crowdfunding Success}

This section aims at investigating the ability of sustainable ventures to improve the success of the calls. The analysis focus on the appraisal of hypothesis 1 to 4 through running regressions based on Equation A to Equation E. As explained in the methodology section, all regressions include the control variables logarithm of the Goal and US. Table 4 presents the results of all regressions discussed in this section. The coefficients for the logistic regressions are calculated using maximum likelihood estimation. The standard errors of the coefficients are shown in brackets.

The control variable logarithm of the Goal suggests, as expected, that campaigns featuring a higher funding target are less likely to obtain this amount. This confirms that previous findings regarding the link between the funding goal and crowdfunding success can also be applied to crowdfunding of sustainable ventures. This is in line with Mollick (2014), Cordova et al. (2015) 
and Kuppuswamy and Bayus (2017) in a general crowdfunding context, and with Hörisch (2015) and Calic and Mosakowski (2016) in a sustainable crowdfunding context.

In Equation A, the logit model also assesses the probability of a successful crowdfunding campaign given certain quality signals. The results suggest that sustainable crowdfunding campaigns which show signals of quality/commitment are, on average, more likely to reach their funding goal. Therefore, Hypothesis 1 is confirmed. More precisely, entrepreneurial quality/commitment improves the rate of success of crowdfunding campaigns. The variable Video is significant at a $1 \%$ level and shows that teams that put time and effort into preparing their pitch are more likely to succeed. Also frequent updates on the campaign page are sign of the engagement of the entrepreneurial team and of its qualities to succeed. The variable Updates is significant at the $1 \%$ level indicating that the likelihood to obtain sufficient funding increases with the number of updates posted. Rewards is significant at the $1 \%$ level and positively related to the funding success of the project. Investing the time to create different forms of the product or bundles and thank you notes, offered to the backers as rewards, signals preparedness.

Equation $B$ tests the effect of gender in the probability of success of a crowdfunding campaign. The results confirm the previous literature concerning the link between gender and crowdfunding success. The variable Gender is significant at the 5\% level and the coefficient also keeps this level of significance when introducing further explanatory variables. This is in line with scholars finding evidence that women are systematically more successful than men on crowdfunding platforms (Barasinska and Schäfer, 2014; Greenberg and Mollick, 2017; Gorbatai and Nelson, 2015; Marom et al., 2016). Thus, Hypothesis 3 is accepted, i.e., the findings support the thesis that crowdfunding reduces the barriers of female entrepreneurs to raise capital.

In Equation $C$, the logit model examines the impact on the success of crowdfunding campaigns of the variable Charity, i.e. whenever part of the profits is attributed to a charitable cause. Profit is significant at a $1 \%$ level suggesting that crowdfunding campaigns, which indicate an allocation to charities of their profits, are more likely to succeed. This is in line with Hörisch (2015), who finds that officially approved non-profit campaigns on indiegogo.com are more likely to success in raising funds on the platform. Ahlers et al. (2015) also find a positive relation between non-profit campaigns and successful funding. Furthermore, one can argue that ventures which indicate a charitable allocation of part of their profits attract potential backers 
with higher sustainable orientation. This further confirms Hypothesis 2. Calic and Mosakowski (2016) also find evidence for a positive influence of sustainable orientation on crowdfunding success. Equation $D$ analyses the complete model confirming the stability of the results (only Charity loses effect and explanatory power but remains significant, this time at 10\%).

Table 4: Regression Results of Crowdfunding Success

This table shows logit regression results for Success as dependent variable. Different explanatory variables are added in regression (A) to (D). Robust standard errors are shown in parentheses. * indicates significance at $10 \%$; ** indicates significance at $5 \% ; * * *$ indicates significance at $1 \%$.

\begin{tabular}{|c|c|c|c|c|}
\hline & (A) & (B) & (C) & (D) \\
\hline VARIABLES & Success & Success & Success & Success \\
\hline LogGoal & $\begin{array}{c}-0.914 * * * \\
(0.105)\end{array}$ & $\begin{array}{c}-0.983 * * * \\
(0.160)\end{array}$ & $\begin{array}{c}-0.932 * * * \\
(0.105)\end{array}$ & $\begin{array}{c}-0.992 * * * \\
(0.160)\end{array}$ \\
\hline US & $\begin{array}{c}0.226 \\
(0.211)\end{array}$ & $\begin{array}{c}0.234 \\
(0.274)\end{array}$ & $\begin{array}{c}0.315 \\
(0.216)\end{array}$ & $\begin{array}{c}0.327 \\
(0.280)\end{array}$ \\
\hline Updates & $\begin{array}{c}0.335 * * * \\
(0.045)\end{array}$ & $\begin{array}{c}0.360 * * * \\
(0.062)\end{array}$ & $\begin{array}{c}0.332 * * * \\
(0.044)\end{array}$ & $\begin{array}{c}0.357 * * * \\
(0.062)\end{array}$ \\
\hline Video & $\begin{array}{c}1.838^{* * *} \\
(0.346)\end{array}$ & $\begin{array}{c}1.977 * * * \\
(0.477)\end{array}$ & $\begin{array}{c}1.776^{* * *} \\
(0.348)\end{array}$ & $\begin{array}{c}1.920 * * * \\
(0.473)\end{array}$ \\
\hline Rewards & $\begin{array}{c}0.111^{* * *} \\
(0.023)\end{array}$ & $\begin{array}{c}0.133 * * * \\
(0.029)\end{array}$ & $\begin{array}{c}0.109^{* * *} \\
(0.022)\end{array}$ & $\begin{array}{c}0.128 * * * \\
(0.028)\end{array}$ \\
\hline Gender & & $\begin{array}{c}0.652 * * \\
(0.270)\end{array}$ & & $\begin{array}{c}0.644 * * \\
(0.272)\end{array}$ \\
\hline Charity & & & $\begin{array}{c}0.905^{* * *} \\
(0.272)\end{array}$ & $\begin{array}{c}0.648 * \\
(0.338)\end{array}$ \\
\hline Constant & $\begin{array}{c}3.186^{* * *} \\
(0.766)\end{array}$ & $\begin{array}{c}3.139 * * * \\
(1.103)\end{array}$ & $\begin{array}{c}3.254 * * * \\
(0.778)\end{array}$ & $\begin{array}{c}3.182 * * * \\
(1.104)\end{array}$ \\
\hline Observations & 869 & 523 & 869 & 523 \\
\hline Pseudo R2 & 0.467 & 0.501 & 0.474 & 0.505 \\
\hline Wald Chi2 & 113.39 & 71.11 & 128.80 & 76.82 \\
\hline
\end{tabular}

\subsection{Post-Campaign Development}

This section investigates the factors that influence the post-campaign performance of sustainable ventures. Table 5 shows the results. 
Table 5: Regression Results of Post-Campaign Development

This table shows logit regression results for Ongoing as dependent variable. Standard errors are shown in parentheses. * indicates significance at $10 \%$; * indicates significance at $5 \%$; *** indicates significance at $1 \%$.

\begin{tabular}{|c|c|c|}
\hline VARIABLES & $\begin{array}{c}\text { (D) } \\
\text { Ongoing }\end{array}$ & $\begin{array}{c}\text { (E) } \\
\text { Ongoing }\end{array}$ \\
\hline Pledge & $\begin{array}{c}0.897 * * * \\
(0.268)\end{array}$ & $\begin{array}{c}1.086 * * * \\
(0.361)\end{array}$ \\
\hline Backers & $\begin{array}{c}-0.597 * \\
(0.311)\end{array}$ & $\begin{array}{c}-0.752 * \\
(0.427)\end{array}$ \\
\hline PledgeByGoal & $\begin{array}{c}0.240 \\
(0.281)\end{array}$ & $\begin{array}{c}0.396 \\
(0.443)\end{array}$ \\
\hline US & $\begin{array}{c}-0.633 * \\
(0.358)\end{array}$ & $\begin{array}{c}-1.309 * * \\
(0.620)\end{array}$ \\
\hline Updates & $\begin{array}{c}-0.009 \\
(0.020)\end{array}$ & $\begin{array}{c}0.003 \\
(0.027)\end{array}$ \\
\hline Rewards & $\begin{array}{c}0.145^{* * *} \\
(0.042)\end{array}$ & $\begin{array}{c}0.200 * * * \\
(0.055)\end{array}$ \\
\hline Charity & & $\begin{array}{c}-1.372 * * \\
(0.690)\end{array}$ \\
\hline Gender & & $\begin{array}{c}0.897 * \\
(0.535)\end{array}$ \\
\hline Constant & $\begin{array}{c}-5.358 * * * \\
(1.307)\end{array}$ & $\begin{array}{c}-6.599 * * * \\
(1.849)\end{array}$ \\
\hline Observations & 261 & 175 \\
\hline Pseudo R2 & 0.157 & 0.226 \\
\hline Wald Chi2 & 29.57 & 28.66 \\
\hline
\end{tabular}

The variable Pledge is significant at the $1 \%$ level, suggesting that the size of the pledge positively influences the post-campaign outcome. This means that despite potential delays in providing the rewards (Mollick, 2014), well-funded initiatives have a higher likelihood of succeeding post-campaign. Regarding the link between overfunding crowdfunding projects and post-campaign success, this study offers no significant insights. The variable Pledge divided by Goal shows no significant results.

Interestingly, the number of backers seem to have a negative influence on the long-term development. This may be due to the time and complexity associated with providing all the rewards for the supporters of the crowdfunding campaign. Entrepreneurs that use crowdfunding will need to be precise when forecasting budget and schedules or the rewards may be at risk of delays (Mollick and Kuppuswamy, 2014). A missing long-term vision and 
therefore failure to forecast correctly the budget and schedules might lead to failure of the project post-campaign.

Similar to the appraisal of factors influencing campaign success, also here the variable US is included to control for this geographic aspect. The variable shows significant results in both regression (1) and (2), at the $10 \%$ and 5\% level respectively. The results suggest that being funded in the US reduces the expected time of a project.

Furthermore, the signals of quality/ preparedness examined in the context of campaign success in the previous section are included in the regressions. The variables Rewards and Updates are added to the regressions. The variable Video is omitted in this context, since the variable is binary and most of the successful campaigns include a video. The number of rewards offered during the campaign has a positive effect on the post-campaign development of the venture. However, the number of updates does not display significant coefficients. Therefore, it is not possible to follow the same line of arguments as in the previous section and conclude that these signals of entrepreneurial passion and preparedness positively influence success. First, at this stage the customers of the now full-fledged company are less likely to find the product through the Kickstarter campaign and hence will not be confronted by these variables. Second, concerning the positive coefficient of the variable Rewards, a project that could offer numerous rewards during the campaign is likely to be able to attract also post-campaign more customers who have different preferences and budget restrictions with their extended product selection. Thus, it is not possible to conclude with certainty that the previously tested quality signals do have a long-term effect on the venture.

The variable Gender is positive and significant at the $10 \%$ level, suggesting that the percentage of female co-founders helps to the post-campaign development of the venture. This leads to the acceptance of Hypothesis 5. Thus, crowdfunding not only reduces the barriers of female entrepreneurs to raise capital, but also enables them to create a healthy business post-campaign.

Finally, the variable Charity is significant at the 5\% level and suggests that ventures who give part of their profit to a charitable cause are less likely to succeed post-campaign. Therefore, the same factor that lead to attracting more backers during the campaign appears to be disadvantageous post-campaign. The crowdfunding campaign may depict a favourable stage to market the project using the charitable allocation of profits. However, after this marketing 
platform ceases to exist for the venture, the use of cash flow necessary to nourish the growing business for other ends may come to the fore. Therefore, Hypothesis 6 is confirmed. 


\section{Discussion}

\subsection{Crowdfunding Success}

This study aims at shading light on the role of crowdfunding as a source of funds for new ventures operating in the realm of sustainability. The analysis follows a two-fold approach. First, the paper aims at understanding whether the sustainable characteristics influence the ability to raise funds via a reward-based crowdfunding platform. A positive connection between sustainable orientation and crowdfunding success could be of aid to a subpart of entrepreneurial efforts commonly plagued by obstacles to obtain sufficient funding (Fedele and Miniaci, 2010; O'Rourke, 2010). Second, this study seeks to gain further insights into the postcampaign development of sustainable ventures, which successfully raised capital through crowdfunding. Further insights concerning the factors influencing the long-term development of these projects could help uncover whether crowdfunding leads to a good efficiency in the allocation of funds aimed at preserving and promoting social and environmental causes.

The literature yields mixed results on the link between sustainable orientation and crowdfunding. Backers of crowdfunding campaigns typically do not look at business plans or collateral but at the ideas and core values behind a project. Thus social entrepreneurial initiatives and crowdfunding should match well in theory (Lehner, 2013). However some empirical analysis contest this assertion (e.g. Hörisch, 2015). The results provided by this study suggest that investors, funding sustainable ventures via reward-based crowdfunding, prefer to support initiatives which contribute to a sustainable cause they perceive as important. In addition, the proportion of the surveyed sustainable ventures reaching their funding goal is in line with the overall success rate on Kickstarter. Combining these two results suggests that crowdfunding is indeed an adequate alternative to traditional forms of financing for sustainable entrepreneurs.

The results confirm that crowdfunding reduces the barriers female entrepreneurs face to raise capital, whereas women historically receive funding via traditional channels at a much lower rate for their projects than men do (Greenberg and Mollick, 2017). However, it is more challenging to understand whether women being more successful in their crowdfunding efforts is due to activist choice homophily. Greenberg and Mollick (2017) find homophily in crowdfunding stronger in categories where women are underrepresented (e.g. games or 
technology, less the 5\% and $10 \%$ female founders respectively) than in a category like fashion with more than $40 \%$ female founders. However, the lack of data concerning the gender distribution of backers in our sample makes it impossible to conclude on the role of activist choice homophily in sustainable crowdfunding.

The analysis shows that, as expected, sustainable ventures that donate part of their profits to charities tend to be more successful in raising funds. This suggests that going further than just claiming sustainable orientation could enhance the chances of success of the funding campaign. The result is in line with Hörisch (2015) and Ahlers et al. (2015), who find that environmental entrepreneurs following officially recognized non-profit campaigns are more likely to succeed in funds raising.

Reward-based crowdfunding frequently gives advantage to projects which create a product that can be pre-ordered by the backers (Hörisch, 2015). Our analysis reveal a significant positive correlation between the number of rewards and a successful outcome of crowdfunding campaigns. This can be interpreted as projects creating more tangible outcomes will be more likely to achieve their funding goal. Therefore, sustainable entrepreneurs who wish to put less emphasis on creating such tangible outcomes could rather consider equity-based crowdfunding as a strategic alternative.

Ultimately, sustainable entrepreneurs need to take the general success factors of crowdfunding into account. This study confirms that lower funding targets are more likely to be met. Thus, especially on all-or-nothing platforms like Kickstarter, the funding goal should be chosen with parsimony. Furthermore, initiators of crowdfunding projects should take the time to prepare for the launch of the campaigns (Cardon et al., 2009; Chan et al, 2009, Mallick, 2014). Signals of quality in form of entrepreneurial passion and preparedness are important. In particular, including a professional video and offering a sufficient number of rewards during their crowdfunding campaign is advisable for sustainable entrepreneurs. This is in line with findings which suggest that social entrepreneurs need to create campaigns that help backers better understand the sustainable mission and to feel a connection to their campaign to boost the success of their campaigns (Parhankangas and Renko, 2017). 


\subsection{Post-Campaign Development}

The results of the data analysis concerning the post-campaign development offer interesting theoretical and practical implications.

First, the ventures included in the sample show an average survival rate of more than $70 \%$ after at least one year of operations. Hence, crowdfunding is indeed not only an adequate alternative of financing for sustainable entrepreneurs, but also leads to the creation of healthy ventures post-campaign. This may encourage future activism in the field of sustainable entrepreneurship and thus help drive global change towards sustainability.

The results confirm that entrepreneurial teams with a higher percentage of female co-founders are more likely to succeed post-campaign. Thus, crowdfunding not only seems to reduce the barriers of female entrepreneurs to raise capital, but also to "empower" them to create a healthy business post-campaign.

The analysis suggest that entrepreneurs should handle donations to charitable causes with caution. Committing to donate a portion of the expected profits to charities may be a powerful tool to market a sustainable mission during the crowdfunding campaign, but has a negative effect on the long-term development of the project. Hence, sustainable entrepreneurs must carefully deliberate about how to act in this matter.

Overall, this study shows that crowdfunding contributes to the development of ventures which drive social change in the three typical dimensions of sustainable development: social; environmental; and economical. First, socially, by opening more opportunities of funding for a part of the population such as women who have been facing more difficulties to access traditional sources of capital. Indeed through crowdfunding, many women have created resilient business after the campaigns. Reward-based crowdfunding platforms also promote more social-oriented project profiles by recompensing with higher rates of success campaigns which donate part of the profits. Secondly, environmentally, by rewarding with higher rates of funds raising — non for profit — projects which aim to lower the impact on the environment or to improve the ecosystem. Crowdfunding therefore stimulates the offer of more environmental conscious goods and services. Finally, economically, by unlocking the concretization of businesses with social and environmental merits that would not be viable otherwise. Crowdfunding is an opportunity for motivated and prepared entrepreneurs willing to develop 
granular ideas or projects, even if the pledge needs to be sufficiently high to create healthy ventures post-campaign.

\subsection{Study Limitations and Future Research}

This study focus on reward-based crowdfunding, excluding other possible approaches like donation based, lending-based, and equity-based. Even though previous research suggests that all forms of crowdfunding are based on similar principles (Mollick, 2014), our results may not be directly transferred to other crowdfunding phenomena. In addition, even among rewardbased platforms, significant differences exist. Similar platforms can have very different dynamics, limiting the applicability of the findings to other platforms. These two points imply that similar research might be carried out drawing on data from other platforms. In particular, one area worthy of investigation are platforms specialised in funding sustainable ventures. Examples of such type of platforms are the Austrian Greenrocket.at, specialised in funding sustainable start-ups, or the similar German project Ecocrowd.de, which was started in 2014. Finally, a meta-analysis of the results found in the crowdfunding literature would improve the comparability and the generalisation of the findings.

\section{Conclusion}

This paper analyses the determinants of success of crowdfunding ventures with sustainable orientation, and examines their success post-campaign. Among other findings, it reveals that the perceived sustainable mission increases the probability of success of the campaign, corroborating previous studies. Projects that promote more tangible products also have higher chances of achieving their funding goal. In addition, the analysis improves the understanding about the post-campaign period of sustainable projects that is understudied in the literature. An average of $70 \%$ of the companies in the sample survive the first year of operation revealing that crowdfunding can offer conditions for healthy sustainable ventures. Women have systematically higher rates of success than men during and after the crowdfunding campaign, meaning that crowdfunding can reduce the barriers of female entrepreneurs to access capital. Finally, donate a higher portion of the future profits improves the chances of success for the campaign, but this should be balanced against the negative effects on the long-term development of the project. Policy-makers willing to stimulate the environmental, the social or 
the economic dimensions of new crowdfunding projects should promote the visibility of crowdfunding as an alternative finance tool, as well as to compensate the negative effects of donations in the expected financial flows of the projects. Future research can improve the understanding about the factors that explain the survival of the projects after the campaign by extending the analysis to other types of crowdfunding models, platforms and products.

\section{Bibliography}

Agrawal, A., Catalini, C., \& Goldfarb, A. (2015). Crowdfunding: Geography, social networks, and the timing of investment decisions. Journal of Economics \& Management Strategy 24(2), 253-274.

Agrawal, A. K., Catalini, C., \& Goldfarb, A. (2011). The geography of crowdfunding. National Bureau of Economic Research (No. w16820).

Ahlers, G. K., Cumming, D., Günther, C., \& Schweizer, D. (2015). Signaling in equity crowdfunding. Entrepreneurship Theory and Practice, 39(4), 955-980.

Allison, T. H., Davis, B. C., Short, J. C., \& Webb, J. W. (2015). Crowdfunding in a prosocial microlending environment: Examining the role of intrinsic versus extrinsic cues. Entrepreneurship Theory and Practice, 39(1), 53-73.

Barasinska, N., \& Schäfer, D. (2014). Is Crowdfunding Different? Evidence on the Relation between Gender and Funding Success from a German Peer-to-Peer Lending Platform. German Economic Review, 15(4), 436-452.

Bartenberger, M., \& Leitner, P. (2013). Crowdsourcing and crowdfunding: approaches to foster social innovation. Paper presented at the Proceedings of the IADIS International Conference Web Based Communities and Social Media 2013.

Baum, J. A., \& Silverman, B. S. (2004). Picking winners or building them? Alliance, intellectual, and human capital as selection criteria in venture financing and performance of biotechnology startups. Journal of Business Venturing 19(3), 411-436.

Belleflamme, P., Lambert, T., \& Schwienbacher, A. (2014). Crowdfunding: Tapping the right crowd. Journal of Business Venturing, 29(5), 585-609.

Belleflamme, P., Lambert, T., \& Schwienbacher, A. (2013). Individual crowdfunding practices. Venture Capital 15(4), 313-333. 
Belleflamme, P., Lambert, T., \& Schwienbacher, A. (2010). Crowdfunding: An industrial organization perspective. Paper presented at the Prepared for the workshop Digital Business Models: Understanding Strategies', held in Paris on June.

Bento, N., Gianfrate, G., \& Groppo, S. V. (2019). Do Crowdfunding Returns Reward Risks? Evidences from Clean-tech Projects. Technological Forecasting and Social Change, forthcoming.

Burtch, G., Ghose, A., \& Wattal, S. (2013). An empirical examination of the antecedents and consequences of contribution patterns in crowd-funded markets. Information Systems Research 24(3), 499-519.

Calic, G., \& Mosakowski, E. (2016). Kicking off social entrepreneurship: how a sustainability orientation influences crowdfunding success. Journal of Management Studies, 53(5), 738-767.

Cardon, M. S., Sudek, R., \& Mitteness, C. (2009). The impact of perceived entrepreneurial passion on angel investing. Frontiers of entrepreneurship research, 29(2), 1.

Charity Navigator (2017). How Do We Classify Charities?. Available at: https://www. charitynavigator.org/index.cfm?bay=content.view\&cpid=34\# (accessed 16 August 2017).

Chen, S., Thomas, S., \& Kohli, C. (2016). What Really Makes a Promotional Campaign Succeed on a Crowdfunding Platform?: Guilt, Utilitarian Products, Emotional Messaging, And Fewer But Meaningful Rewards Drive Donations. Journal of Advertising Research 56(1), 81-94.

Chen, X.-P., Yao, X., \& Kotha, S. (2009). Entrepreneur passion and preparedness in business plan presentations: a persuasion analysis of venture capitalists' funding decisions. Academy of Management journal, 52(1), 199-214.

Cordova, A., Dolci, J., \& Gianfrate, G. (2015). The determinants of crowdfunding success: Evidence from technology projects. Procedia-Social and Behavioral Sciences, 181, 115-124.

Cumming, D. J., Leboeuf, G., \& Schwienbacher, A. (2014). Crowdfunding models: Keep-itall vs. all-or nothing (SSRN Working Paper No. 2447567). https://papers.ssrn.com/sol3/Papers.cfm?abstract_id=2447567 [last accessed in 10/2/2019]

Dai, N., Jo, H., \& Kassicieh, S. (2012). Cross-border venture capital investments in Asia: Selection and exit performance. Journal of Business Venturing 27(6), 666-684.

Drover, W., Busenitz, L., Matusik, S., Townsend, D., Anglin, A., \& Dushnitsky, G. (2017). A Review and Road Map of Entrepreneurial Equity Financing Research: Venture Capital, 
Corporate Venture Capital, Angel Investment, Crowdfunding, and Accelerators. Journal of Management 43(6), 1820-1853.

Drover, W., Wood, M. S., \& Fassin, Y. (2014). Take the money or run? Investors' ethical reputation and entrepreneurs' willingness to partner. Journal of Business Venturing 29(6), 723-740.

Drury, J., \& Stott, C. (2011). Contextualising the crowd in contemporary social science. Contemporary Social Science, 6(3), 275-288.

Etter, V., Grossglauser, M., \& Thiran, P. (2013). Launch hard or go home!: predicting the Formatada: Alemão (Alemanha) success of kickstarter campaigns. Paper presented at the Proceedings of the first ACM conference on online social networks.

Fedele, A., \& Miniaci, R. (2010). Do social enterprises finance their investments differently from for-profit firms? The case of social residential services in Italy. Journal of social entrepreneurship, 1(2), 174-189.

Franke, N., Gruber, M., Harhoff, D., \& Henkel, J. (2008). Venture capitalists' evaluations of start-up teams: trade-offs, knock-out criteria, and the impact of VC experience. Entrepreneurship Theory and Practice 32(3), 459-483.

Frydrych, D., Bock, A. J., Kinder, T., \& Koeck, B. (2014). Exploring entrepreneurial legitimacy in reward-based crowdfunding. Venture Capital 16(3), 247-269.

Gerber, E. M., Hui, J. S., \& Kuo, P.-Y. (2012). Crowdfunding: Why people are motivated to post and fund projects on crowdfunding platforms. Paper presented at the Proceedings of the International Workshop on Design, Influence, and Social Technologies: Techniques, Impacts and Ethics.

Giudici, G., Guerini, M., \& Rossi Lamastra, C. (2013). Why crowdfunding projects can succeed: the role of proponents' individual and territorial social capital (SSRN Working Paper No. 2255944). Available at http://ssrn.com/abstract=2255944 [last accessed in $8 / 2 / 2019]$.

Gorbatai, A., \& Nelson, L. (2015). The Narrative Advantage: Gender and the Language of Crowdfunding. Haas School of Business UC Berkeley. Research Papers.

Greenberg, J., \& Mollick, E. (2017). Activist choice homophily and the crowdfunding of female founders. Administrative Science Quarterly, 62(2), 341-374.

Gu, Q., \& Lu, X. (2014). Unraveling the mechanisms of reputation and alliance formation: A study of venture capital syndication in China. Strategic Management Journal 35(5), 739-750.

Hemer, J. (2011). A snapshot on crowdfunding. Working papers firms and region (No. $\mathrm{R} 2 / 2011)$ 
Hogue, J. (2017). 10 Crowdfunding Statistics to Raise More Money. 7 November, available at https://www.crowd101.com/crowdfunding-success-statistics-raise-money-online/ [last accessed in $8 / 2 / 2019]$.

Hörisch, J. (2015). Crowdfunding for environmental ventures: an empirical analysis of the influence of environmental orientation on the success of crowdfunding initiatives. Journal of Cleaner Production, 107, 636-645.

Hu, M., Li, X., \& Shi, M. (2015). Product and pricing decisions in crowdfunding. Marketing Science 34(3), 331-345.

Hui, J. S., Gerber, E., \& Greenberg, M. (2012). Easy money? The demands of crowdfunding work. Northwestern University, Segal Design Institute, 1-11. Available at http://egerber.mech.northwestern.edu/wp-content/uploads/2012/11/Easy-Money-_TheDemands-of-CrowdfundingWork-_2012.pdf [last accessed in 8/2/2019].

Ibrahim, N. (2012). The model of crowdfunding to support small and micro businesses in Indonesia through a web-based platform. Procedia Economics and Finance, 4, 390397.

Jell, F., Block, J. H., \& Henkel, J. (2011). Innovativität als Kriterium bei Venture-CapitalInvestitionsentscheidungen. Kredit und Kapital 44(4), 509-541.

Jovanovic, T. (2018). Crowdfunding: What do we know so far?. International Journal of Innovation and Technology Management 16(1) 1950009.

Kang, L., Jiang, Q., \& Tan, C. H. (2017). Remarkable advocates: An investigation of geographic distance and social capital for crowdfunding. Information \& Management, 54(3), 336-348.

Koch, J.-A., \& Siering, M. (2015). Crowdfunding success factors: the characteristics of successfully funded projects on crowdfunding platforms.

Kuppuswamy, V., \& Bayus, B. L. (2017). Crowdfunding creative ideas: The dynamics of project backers in Kickstarter. in L.Hornuf and D.Cumming (eds), The Economics of Crowdfunding: Startups, Portals, and Investor Behavior, Heidelberg: Springer International, Chapter 8.

Lehner, O. M. (2013). Crowdfunding social ventures: a model and research agenda. Venture Capital, 15(4), 289-311.

Lehner, O. M., \& Nicholls, A. (2014). Social finance and crowdfunding for social enterprises: A public-private case study providing legitimacy and leverage. Venture Capital, 16(3), 271-286.

Li, Y., \& Zahra, S. A. (2012). Formal institutions, culture, and venture capital activity: A cross-country analysis. Journal of Business Venturing, 27(1), 95-111. 
Lin, Y., Boh, W. F., \& Goh, K. H. (2014). How different are crowdfunders? Examining archetypes of crowdfunders and their choice of projects. In: Academy of Management Proceedings (Vol. 2014, No. 1, p. 13309). Briarcliff Manor, NY 10510: Academy of Management.

Lukkarinen, A., Teich, J. E., Wallenius, H., \& Wallenius, J. (2016). Success drivers of online equity crowdfunding campaigns. Decision Support Systems 87, 26-38.

Marom, D., Robb, A., \& Sade, O. (2016). Gender dynamics in crowdfunding (Kickstarter): Evidence on entrepreneurs, investors, deals and taste-based discrimination.

Massolution, C. L. (2012). Crowdfunding industry report: market trends, composition and crowdfunding platforms. Research Report, available at: www. crowdfunding. nl/wpcontent/uploads/2012/05/92834651-Massolution-abridged-Crowd-Funding-IndustryReport1. pdf [last accessed in 8/2/2019].

Mendes-Da-Silva, W., Rossoni, L., Conte, B. S., Gattaz, C. C., \& Francisco, E. R. (2016). The impacts of fundraising periods and geographic distance on financing music production via crowdfunding in Brazil. Journal of Cultural Economics 40(1), 75-99.

Mitra, T., \& Gilbert, E. (2014). The language that gets people to give: Phrases that predict success on kickstarter. Paper presented at the Proceedings of the 17th ACM conference on Computer supported cooperative work \& social computing.

Mollick, E. (2014). The dynamics of crowdfunding: An exploratory study. Journal of business venturing, 29(1), 1-16.

Mollick, E. R., \& Kuppuswamy, V. (2014). After the campaign: Outcomes of crowdfunding.

Moritz, A., \& Block, J. H. (2016). Crowdfunding: A literature review and research directions. In: Crowdfunding in Europe (pp. 25-53). Springer, Cham.

O'Rourke, A. R. (2010). How Venture Capital Can Help. Making Ecopreneurs: Developing Sustainable Entrepreneurship, 165.

Ordanini, A., Miceli, L., Pizzetti, M., \& Parasuraman, A. (2011). Crowd-funding: transforming customers into investors through innovative service platforms. Journal of Service Management 22(4), 443-470.

Ortas, E., Burritt, R. L., \& Moneva, J. M. (2013). Socially Responsible Investment and cleaner production in the Asia Pacific: does it pay to be good? Journal of Cleaner Production, 52, 272-280.

Parhankangas, A., \& Renko, M. (2017). Linguistic style and crowdfunding success among social and commercial entrepreneurs. Journal of Business Venturing, 32(2), 215-236. 
Qiu, C. (2013). Issues in crowdfunding: Theoretical and empirical investigation on Kickstarter (SSRNWorking Paper No. 2345872). Available at https://papers.ssrn.com/sol3/papers.cfm?abstract_id=2345872 [last accessed in 8/2/2019].

Saxton, G. D., \& Wang, L. (2014). The social network effect: The determinants of giving through social media. Nonprofit and Voluntary Sector Quarterly 43(5), 850-868.

Schaltegger, S. (2002). A Framework for Ecopreneurship. Greener Management International(38), 26-30.

Schaltegger, S., \& Wagner, M. (2011). Sustainable entrepreneurship and sustainability innovation: categories and interactions. Business strategy and the environment, 20(4), 222-237.

Schwienbacher, A., \& Larralde, B. (2010). Crowdfunding of small entrepreneurial ventures.

Short, J. C., Ketchen, D. J., McKenny, A. F., Allison, T. H., \& Ireland, R. D. (2017). Research on Crowdfunding: Reviewing the (Very Recent) Past and Celebrating the Present. Entrepreneurship Theory and Practice, 41(2), 149-160.

Tian, X. (2011). The causes and consequences of venture capital stage financing. Journal of Financial Economics 101(1), 132-159.

Vasileiadou, E., Huijben, J. C. C. M., \& Raven, R. P. J. M. (2016). Three is a crowd? Exploring the potential of crowdfunding for renewable energy in the Netherlands. Journal of Cleaner Production, 128, 142-155.Venkataraman, S. (2004). Regional transformation through technological entrepreneurship. Journal of Business Venturing 19(1), 153-167.

Vismara, S. (2016). Equity retention and social network theory in equity crowdfunding. Small Business Economics 46(4), 579-590.

Wash, R., \& Solomon, J. (2014, February). Coordinating donors on crowdfunding websites. In Proceedings of the 17th ACM conference on Computer supported cooperative work \& social computing (pp. 38-48). ACM.

Xu, B., Zheng, H., Xu, Y. and Wang, T. (2016). Con ${ }^{-}$gurational paths to sponsor satisfaction in crowdfunding. Journal of Business Research 69, 2: 915-927. 